ISSN: 2302-8556

E-Jurnal Akuntansi Universitas Udayana

Vol.26.3.Maret (2019): 1969 - 1991

DOI: https://doi.org/10.24843/EJA.2019.v26.i03.p11

\title{
Pengaruh Budaya Organisasi Pada Hubungan Antara Penerapan Good Government Governance dan Kinerja Pegawai
}

\author{
Anak Agung Ngurah Mahaputra Bismantara ${ }^{1}$ \\ Made Gede Wirakusuma ${ }^{2}$ \\ ${ }^{1,2}$ Fakultas Ekonomi dan Bisnis Universitas Udayana (Unud), Bali, Indonesia \\ e-mail: gunkwahbisma@gmail.com
}

\begin{abstract}
ABSTRAK
Penelitian ini bertujuan untuk memperoleh bukti empiris budaya organisasi sebagai pemoderasi antara penerapan prinsip-prinsip GGG terhadap kinerja pegawai pada DPMPTSP di Kota Denpasar. Metode pengumpulan data dalam penelitian ini adalah metode survey dengan menggunakan teknik kuesioner. Metode penentuan sampel menggunakan rumus Slovin. Sampel yang digunakan berjumlah 61 pegawai. Teknik analisis yang digunakan dalam penelitian ini adalah Moderated Regression Analysis. Hasil penelitian ini menunjukkan bahwa prinsip prinsip GGG berpengaruh positif terhadap kinerja pegawai pada DPMPTSP di Kota Denpasar dan budaya organisasi memperkuat pengaruh prinsip prinsip GGG terhadap kinerja pegawai pada DPMPTSP di Kota Denpasar.
\end{abstract}

Kata kunci: Good Government Governance, budaya organisasi, dan kinerja pegawai

\begin{abstract}
The purpose of this study is to obtain empirical evidence of Organizational Culture as a moderator between the application of Good Government Governance and Employee Performance. The sample is determined using the Slovin method. The population of this research is 61 people who work in Dinas Penanaman Modal Denpasar City. The method of data collection is done using the questionnaire method and the data analysis techniques used are factor analysis and moderated regression analysis. Based on the analysis it was found that Good Government Governance had a positive effect on Employee Performance, and Organizational Culture was able to strengthen the effect between Good Government Governance and Employee Performance.

Keywords: Good Government Governance, Organizational Culture, and Employee Performance
\end{abstract}

\section{PENDAHULUAN}

Sejak tahun 90-an, istilah Good Corporate Governance (GCG) sangat akrab kita dengar baik itu di kampus dan penerapanya di kalangan perusahaan maupun instansi. Pengelolaan instansi (Government Governance) dalam pelayanan publik merupakan implementasi yang sama dengan Good Corporate Governance. Bukan lagi sekedar kewajiban, namun telah menjadi kebutuhan bagi setiap perusahaan dan instansi untuk menjalankannya. 
Anak Agung Ngurah Mahaputra Bismantara dan Made Gede Wirakusuma. Pengaruh ...

Good Government Governance memiliki prinsip-prinsip yang harus dijalankan, prinsip-prinsp tersebut antara lain independensi, akuntabilitas, transparansi, responsibilitas, kesetaraan dan kewajaran, yang diperlukan guna mencapai suatu kinerja yang berkelanjutan dengan memperhatikan kepentingan pihak yang bersangkutan. Prinsip-prinsip Good Government Governance harus dikelola secara independen agar masing-masing organ instansi dapat berfungsi tanpa saling mendominasi dan tidak dapat di intervensi oleh pihak lain. Kewajaran (Fairness) instansi harus memperhatikan kepentingan masyarakat berdasarkan asas perilaku yang setara (equal treatment) serta asas manfaat yang wajar. Menurut Arifin (2006) beberapa manfaat dari penerapan Good Government Governance ialah pertama membuat proses pengembalian keputusan menjadi mudah, sehingga kinerja instansi berpengaruh positif. Kedua menghindari penyalahgunaan wewenang oleh pihak direksi dalam pengelolaan instansi.

Budaya organisasi ialah keyakinan semua anggota organisasi akan sistem nilai-nilai serta yang diterapkan, dikembangkan, serta dipelajari secara berkesinambungan, bermanfaat sebagai sistem perekat, dan dapat dijadikan sebagai acuan berperilaku dalam organisasi guna mencapai tujuan organisasi yang telah ditetapkan (Temaja, 2015). Menurut Wallach (1983), budaya organisasi digunakan sebagai suatu pedoman bersama oleh seluruh anggota organisasi dalam meyakinkan segala sesuatu yang terjadi di sekitar mereka. Oleh karena itu dapat dikatakan bahwa budaya organisasi dapat mempengaruhi perilaku individu dan kelompok dalam organisasi. 
Sebagai organisasi sektor publik pemerintah daerah dituntut agar memiliki kinerja yang berorientasi pada kepentingan masyarakat dan mendorong pemerintah untuk senantiasa tanggap akan tuntunan lingkunganya dengan berupaya memberikan pelayanan terbaik secara transparan, akuntabilitas dan berkualitas, serta adanya pembagian tugas yang baik pada pemerintah, sehingga pelayanan masyarakat dapat di laksanakan dengan sebaik baiknya. Baik buruknya kinerja para aparatur pemerintahan dapat ditentukan oleh beberapa faktor, namun faktor yang dijadikan pertimbangan ada dua faktor yaitu penerapan prinsip prinsip good governmentgovernance dan budaya organisasi.

Menurut Sedarmayanti, (2011:260) kinerja adalah catatan mengenai outcome yang dihasilkan dari suatu aktivitas tertentu, selama kurun waktu tertentu pula. Costello (dalam Wibowo, 2012:9) menyatakan bahwa manajemen kinerja merupakan dasar dan kekuatan pendorong yang berada di belakang semua keputusan organisasi, usaha kerja dan alokasi sumber daya. Sedangkan pendapat Wibowo, (2012:8) menyatakan bahwa kinerja sumber daya manusia merupakan proses komunikasi yang dilakukan secara terus menerus dalam kemitraan antara pegawai dengan atasan langsungnya. Proses merupakan suatu sistem, memiliki sejumlah bagian yang semuanya harus diikutsertakan, apabila hendak memberikan nilai tambah bagi organisasi, manajer dan pegawai.

Berdasarkan uraian di atas penulis tertarik untuk melakukan penelitian dengan judul: "Pengaruh Budaya Organisasi pada Hubungan antara Penerapan Good Government Governance dan Kinerja Pegawai ( Studi Empiris pada Dinas Penanaman Modal Kota Denpasar )“.Untuk dapat menciptakan sebuah 
Anak Agung Ngurah Mahaputra Bismantara dan Made Gede Wirakusuma. Pengaruh ...

keunggulan dalam hal pelayanan publik maka pemerintahan penting untuk menerapkan prinsip-prinsip good governmentgovernance.

Menurut Jensen dan Meckling (1976) hubungan kontrak antara pemilik dan manajemen sejalan dengan agency theory. Agency theory menggunakan tiga asumsi sifat manusia antara lain manusia pada umumnya mementingkan diri sendiri (self interest), manusia memiliki daya pikir terbatas mengenai persepsi masa mendatang (bounded rationality), dan manusia selalu menghindari resiko (risk averse) (Eisenhardt (1989)). Teori keagenan menggambarkan pihak manajemen sebagai agen lebih banyak tahu tentang instansi dan bisa memanfaatkan posisinya tersebut untuk keuntungan pihaknya (Ratih, 2011).

Tanpa sepengetahuan dari prinsipal, agen mungkin mengetahui lebih banyak mengenai kondisi instansi yang sebenarnya dibandingkan prinsipal sehingga dalam hubungan keagenan dapat tercipta konflik kepentingan (Adhi dan Siti, 2012). Terjadinya konflik kepentingan dalam organisasi bisnis menyebabkan kinerja manajer dan instansi menjadi aspek yang penting untuk diperhatikan (Moradi dkk., 2012). Konflik kepentingan dapat terjadi dalam organisasi bisnis dikarenakan prinsipal sebagai pihak pemilik tidak dapat selalu memonitor aktivitas manajemen untuk memastikan apakah manajemen telah bekerja sesuai dengan keinginan prinsipal. Terkadang informasi yang disampaikan tidak sesuai dengan kondisi instansi yang sebenarnya (Savitri, 2010). Keadaan inilah yang disebut dengan asimetri informasi (information asymetric).Ujiantho dan Pramuka (2007) menyatakan adanya informasi yang tidak simetris tersebut dapat mendorong manajemen (agen) untuk menyembunyikan beberapa informasi yang 
tidak diketahui oleh pemilik (prinsipal) hal itu dilakukan untuk memaksimalkan keuntungan agen. Agen dapat termotivasi untuk melaporkan informasi yang tidak sebenarnya kepada prinsipal, terutama jika informasi tersebut berkaitan dengan pengukuran kinerja agen. Corporate governance sebagai salah satu mekanisme pengendalian internal yang paling penting dari masalah lembaga dalam mengurangi salah satu dampak dari hubungan keagenan yaitu asimetri informasi (Clemente dan Labat, 2009). Menurut Fathi (2013) dengan publikasi informasi mengenai kondisi instansi dan kinerja instansi serta manajemen dapat mengurangi konflik agensi yang terjadi dalam hubungan keagenan suatu organisasi.

Teori stewardship merupakan teori yang dicetuskan pada tahun 1991 oleh Donaldson dan Davis. Teori inimenggambarkan situasi para manajer tidak termotivasi oleh tujuan - tujuan individu tetapi lebih merujuk kepada sasaran hasil utama mereka untuk kepentingan organisasi (Riyadi dan Yulianto, 2014). Teori ini memiliki asumsi bahwa manajer adalah pelayan (steward) instansi yang baik dan rajin bekerja untuk mencapai pelayanan publik yang baik. Teori stewardship mempunyai dasar psikologi dan sosiologi yang telah dirancang dimana para pihak manajemen sebagai steward termotivasi untuk bertindak sesuai keinginan prinsipal, selain itu perilaku steward tidak akan meninggalkan organisasinya sebab steward berusaha mencapai sasaran organisasinya (Riyadi, 2014).

Stewardship theory ini timbul berdasarkan kepercayaan pada masingmasing pihak. Pihak yang memberikan kepercayaan disebut principal dan pihak yang diberi kepercayaan adalah steward (Wijaya dan Sudarma, 2015).Teori ini didesain bagi para peneliti untuk menguji situasi dimana para pihak manajemen 
Anak Agung Ngurah Mahaputra Bismantara dan Made Gede Wirakusuma. Pengaruh ...

dalam instansi sebagai pelayan dapat termotivasi untuk bertindak dengan cara terbaik pada prinsipalnya.

Good Government Governance yang baik akan meningkatkan kinerja perusahaan maupun instansi. Implementasi Good Government Governance memiliki hubungan dengan kontrol internal dari perusahaan. Konsep Good Government Governance dapat menimbulkan kinerja yang baik bagi suatu organisasi (Gozali, 2012). Menurut Andriyanto (2013) Good Government Governance terbukti mampu memengaruhi kinerja manajerial secara positif signifikan. Kinerja manajerial yang lebih baik akan terjamin dengan diterapkannya prinsip-prinsip Good Government Governance danadanya dukungan dari semua pihak. Good Government Governance merupakan instrumen pokok entitas guna mencapai kualitas kinerja yang baik.

Penerapan Good Government Governance dapat mendorong kinerja, karena memberikan arahan yang baik dalam mengelola instansi dan menjamin tindakan manajemen, sehingga efektivitas dan efisiensi pengelolaan isntansi dapat tercapai serta menciptakan perlindungan terhadap seluruh kepentingan stakeholder. Pengelolaan instansi yang baik akan menumbuhkan kepercayaan masyarakat.

$\mathrm{H}_{1}$ : Penerapan Good Government Governance berpengaruh terhadap kinerja pegawai di Dinas Penanaman Modal dan Pelayanan Terpadu Satu Pintu Kota Denpasar.

Keberhasilan dalam menerapkan Good Government Governance dipengaruhi oleh faktor baik dari dalam dan luar lingkup organisasi. Salah satu faktor internal yang berpengaruh terhadap keberhasilan penerapan prinsip-prinsip Good Government Governance adalah budaya organisasi (Indah, 2013). Menurut 
Cartwright dalam Moeljono (2005:75) budaya organisasi yang baik menjadi determinan dari Good Government Governance.

Menurut penelitian Shahzad (2012) menyatakan bahwa budaya organisasi memiliki dampak terhadap kinerja karyawan dan menyebabkan peningkatan pada produktivitas dan meningkatkan kinerja organisasi. Purnama (2013) mengungkapkan bahwa budaya organisasi juga berdampak secara signifikan pada kinerja organisasi dalam jangka waktu yang lebih lama. Budaya organisasi bahkan mungkin menjadi faktor yang berkontribusi besar dalam menentukan berhasil tidaknya organisasi dalam dekade mendatang karena budaya organisasi merupakan fondasi untuk membangun organisasi.

Budaya organisasi yang lemah akan berdampak pada aspek kewajaran dari sikap pegawai yang dicerminkan dari tugas-tugas pegawai yang tidak terselesaikan dengan baik. Hal ini terlihat dari kurangnya movitasi dalam bekerja, timbulnya rasa curiga, tidak lancarnya komunikasi, terkikisnya loyalitas pada tugas utamanya dan komitmen pegawai pada perusahaan (Supartha, 2008).

$\mathrm{H}_{2}$ : Budaya organisasi memoderasi hubungan antara Good Government Governance dan kinerja pegawai di Dinas Penanaman Modal Kota Denpasar.

\section{METODE PENELITIAN}

Penelitian ini dilakukan pada pada Gedung Graha Sewaka Dharma di Dinas Penanaman Modal dan Pelayanan Terpadu Satu Pintu Kota Denpasar dengan memberikan kuesioner pada instansi yang dijadikan sampel penelitian. Objek dari penelitian ini adalah prinsip - prinsip good government governance yang terdiri dari transparency, accountability, responsibility, indepedency dan fairness serta 
Anak Agung Ngurah Mahaputra Bismantara dan Made Gede Wirakusuma. Pengaruh ...

budaya organisasi untuk mengukur kinerja pegawai di Dinas Penanaman Modal dan Pelayanan Terpadu Satu Pintu Kota Denpasar.

Definisi operasional variabel adalah penentuan construct sehingga menjadi variabel yang dapat diukur. Definisi operasional menjelaskan cara tertentu yang digunakan oleh peneliti dalam mengoperasionalisasikan construct, sehingga memungkinkan bagi peneliti yang lain untuk melakukan replikasi pengukuran dengan cara yang sama atau mengembangkan cara pengukuran construct yang lebih baik (Indriantoro, 2013:69). Definisi operasional variabel dalam penelitian ini berupa sejumlah pertanyaan dalam kuesioner yang diadopsi dari kuesioner penelitian Putri (2017), berhubungan dengan variabel - variabel yang hendak diukur antara lain.

Aspek transparency atau keterbukaan akan diukur dengan 4 (empat) pertanyaan mengenai kewajiban bagi para pengelola untuk menjalankan prinsip keterbukaan dalam proses keputusan dan penyampaian informasi. Keterbukaan dalam menyampaikan informasi juga mengandung arti bahwa informasi yang disampaikan harus lengkap, benar, dan tepat waktu kepada semua pemangku kepentingan.

Aspek accountability diukur dengan 4 (empat) pertanyaan mengenai pentingnya penciptaan sistem pengawasan yang efektif berdasarkan pembagian kekuasaan yang meliputi monitoring, evaluasi, dan pengendalian terhadap manajemen untuk meyakinkan bahwa manajemen bertindak sesuai dengan pihakpihak yang berkepentingan. Aspek responsibility atau pertanggungjawaban diukur dengan 4 (empat) pertanyaan mengenai tanggung jawab sosial instansi, 
profesionalisme, etika, serta lingkungan bisnis dalam instansi apakah sudah cukup baik atau belum.

Aspek indepedency diukur dengan 4 (empat) pertanyaan mengenai penggunaan tenaga ahli dalam instansi, pengaruh pihak luar, benturan kepentingan, dan aktivitas instansi. Aspek fairness diukur dengan 4 (empat) pertanyaan mengenai keadilan dan kesetaraan di dalam memenuhi hak-hak masyarakat yang timbul berdasarkan perjanjian dan peraturan perundangundangan yang berlaku. Aspek Budaya Organisasi diukur dengan 4 (empat) pertanyaan mengenai kebiasaan-kebiasaan yang terjadi dalam hirarki organisasi yang mewakili norma-norma perilaku dan diikuti oleh para anggota dalam organisasi. Aspek Kinerja Pegawai diukur dengan 4 (empat) pertanyaan mengenai tingkat pelaksanaan tugas yang dapat dicapai seseorang, unit atau divisi dengan menggunakan kemampuan yang ada dan batasan-batasan yang telah ditetapkan untuk mencapai tujuan organisasi.

Data berdasarkan sumbernya yang digunakan dalam penelitian ini adalah data primer penelitian ini adalah skor jawaban kuesioner yang diberikan kepada responden penelitiandi Dinas Penanaman Modal dan Pelayanan Terpadu Satu Pintu Kota Denpasar. Data sekunder dalam penelitian ini adalah daftar pegawaidi Dinas PenanamanModal dan Pelayanan Terpadu Satu Pintu Kota Denpasar.

Populasi dalam penelitian ini adalah seluruh pegawai di Dinas PenanamanModal dan Pelayanan Terpadu Satu Pintu Kota Denpasaryang tergolong aktif. Berdasarkan data yang diperoleh dari Dinas PenanamanModal dan Pelayanan Terpadu Satu Pintu Kota Denpasar, jumlah keseluruhan pegawai 
Anak Agung Ngurah Mahaputra Bismantara dan Made Gede Wirakusuma. Pengaruh ...

adalah 155 orang yang terdiri dari 82 orang Pegawai Negeri Sipil dan 73 orang tenaga kontrak.

Cara pengambilan sampel dari sebuah populasi adalah dengan membagi terlebih dahulu anggota populasinya menjadi kelompok yang lebih kecil. Kemudian diambil sampel secara acak. Berdasarkan data dari Dinas Penanaman Modal Kota Denpasar, jumlah keseluruhan pegawai adalah 155 orang yang terdiri dari 82 orang Pegawai Negeri Sipil dan 73 orang tenaga kontrak. Penentuan total jumlah sampel akan diambil menggunakan rumus Slovin (Umar, 2009:78) yaitu sebagai berikut:

$\mathrm{n}=\frac{N}{1+N(e)^{2}}$

Keterangan:

$\mathrm{n}=$ jumlah sampel

$\mathrm{N}=$ ukuran populasi

$\mathrm{e}=$ persen kelonggaran ketidaktelitian karena kesalahan pengambilan sampel yang masih ditolelir atau diinginkan

Populasi yang berjumlah 155 orang dan tingkat kesalahan yang digunakan 10 persen maka perhitungan penentuan sampel yang akan diteliti dilakukan sebagai berikut:

$\mathrm{n}=\frac{155}{1+155(0,01)}$

$\mathrm{n}=60,78(61$ orang $)$

Kemudian sampel sebanyak 61 orang tersebut dialokasikan ke masing masing departemen di Dinas Penanaman Modal Kota Denpasar secara proporsional.

Hasil dari pengumpulan data akan dihimpun dan diolah dengan menggunakan alat bantu berupa progran aplikasi SPSS. Pengolahan data ini untuk 
menguji hipotesis yang telah ditetapkan diterima atau ditolak. Dalam penelitian ini karena adanya variabel moderasi maka teknik analisis datanya menggunakan persamaan regresi melalui uji interaksi atau sering disebut dengan Moderated Regresion Analysis (MRA). MRA merupakan aplikasi khusus regresi berganda linier dimana dalam persamaan regresinya mengandung unsur interaksi (perkalian dua atau lebih variabel independen) sebagai berikut (Ghozali, 2009:221)

$\mathrm{Y}=\alpha+\beta_{1} \mathrm{X}_{1}+\beta_{2} \mathrm{X}_{2}+\beta_{3} \mathrm{X}_{1} \cdot \mathrm{X}_{2}+\mathrm{e}$

Dimana :

$\mathrm{Y}=$ Variabel terikat (kinerja pegawai)

$\alpha \quad=$ Konstanta

$\beta_{1}, \beta_{2} \quad=$ Koefisien regresi untuk $X_{1}$ dan $X_{2}$

$\mathrm{X}_{\mathrm{I}} \quad=$ Variabel bebas (Good Government Governance)

$\mathrm{X}_{2} \quad=$ Variabel pemoderasi (Budaya Organisasi)

$\mathrm{e} \quad=$ Standar error

Dari analisis regresi diamati Goodness of Fit-nya yaitu: koefisien determinasi $\left(\mathrm{R}^{2}\right)$, uji kelayakan model (Uji F), dan uji hipotesis (Uji t).

\section{HASIL DAN PEMBAHASAN}

Responden yang dipilih dalam penelitian ini adalah 61 orang pegawai di Dinas Penanaman Modal Kota Denpasardimana termasuk orang - orang yang mengetahui wewenang dan tugas pengelolaan dinas dan fungsi - fungsi badan pengawas dalam menilai peranan good government governanceterhadap kinerja pegawai. Berdasarkan kriteria yang ditetapkan maka sampel diambil sebanyak 61 orang dari jumlah keseluruhan 155 orang pegawai yang terdiri dari 82 orang Pegawai Negeri Sipil dan 73 orang tenaga kontrak diDinas Penanaman Modal dan Pelayanan Terpadu Satu Pintu Kota Denpasar. 
Tabel 1. Ringkasan Pengiriman dan Pengembalian Kuesioner

\begin{tabular}{lll}
\hline Kuesioner & Jumlah & Persentase (\%) \\
\hline Kuesioner yang disebarkan & 61 & $100 \%$ \\
Kuesioner yang kembali & 61 & $100 \%$ \\
Kuesioner yang digunakan & 61 & $100 \%$ \\
\hline Sumber: Data diolah, 2018 & &
\end{tabular}

Berdasarkan Tabel 1. dapat diketahui bahwa jumlah kuesioner yang tersebar ke responden dan kembali sebanyak 61 kuesioner. Tidak ada kuesioner yang tidak kembali sehingga secara keseluruhan sebanyak 61 kuesioner yang dapat digunakan.

Karakteristik responden berdasarkan jenis kelamin dapat digunakan untuk mengetahui proporsi responden laki-laki dan perempuan pada Dinas Penanaman Modal Kota Denpasar. Pada Tabel 4.3 menunjukkan bahwa jumlah responden laki-laki sebanyak 42 orang (68\%) dan jumlah responden perempuan sebanyak 19 orang (31\%). Hal ini menunjukkan bahwa mayoritas responden adalah laki-laki.

Karakteristik responden berdasarkan usianya digunakan untuk mengetahui rentang usia karyawan yang bekerja pada Dinas Penanaman Modal Kota Denpasar. Tabel 4.3 menunjukkan bahwa responden yang berusia 21 sampai 25 tahun sebanyak 5 orang (8\%), usia 26 sampai 30 tahun sebanyak 19 orang (31\%), usia 31 sampai 35 tahun sebanyak 10 orang (16\%), dan sebanyak 27 orang yang memiliki usia lebih dari 35 tahun (44\%). Hal ini menunjukkan bahwa mayoritas responden berusia lebih dari 35 tahun.

Karakteristik responden berdasarkan tingkat pendidikan terakhir digunakan sebagai indikator untuk mengetahui tingkat pendidikan yang ditempuh oleh responden pada Dinas Penanaman Modal Kota Denpasar. Tabel 4.3 menunjukkan 
bahwa responden yang memiliki tingkat pendidikan pada jenjang SMA / SMK sebanyak 2 orang (3\%), pada jenjang D3 sebanyak 21 orang (34\%), pada jenjang S1 sebanyak 33 orang (54\%), dan responden yang memiliki pendidikan pada jenjang S2 sebanyak 5 orang (8\%). Hal ini menunjukkan bahwa berdasarkan tingkat pendidikan terakhir yang mendominasi adalah responden dengan tingkat pendidikan S1.

Karakteristik responden berdasarkan lama bekerja digunakan sebagai indikator untuk mengetahui pengalaman responden dalam bekerja pada Dinas Penanaman Modal Kota Denpasar. Tabel 2. menunjukkan bahwa sebanyak 4 orang (6\%) yang bekerja antara 1 sampai 2 tahun. Sebanyak 12 orang (19\%) yang bekerja selama 2 sampai 3 tahun, dan 45 orang (73\%) yang bekerja selama lebih dari 3 tahun. Hal ini menunjukkan bahwa mayoritas responden telah bekerja selama lebih dari 3 tahun.

Tabel 2.

Karakteristik Responden

\begin{tabular}{llcc}
\hline No. & Karakteristik & Jumlah & Persentase $(\%)$ \\
\hline \multirow{3}{*}{1} & Jenis Kelamin: & & \\
& Laki-laki & 42 & 68 \\
& Perempuan & 19 & 31 \\
& Total & 61 & 100 \\
& Umur: & & \\
21-25 Tahun & 5 & 8 \\
26-30 Tahun & 19 & 31 \\
31-35 Tahun & 10 & 16 \\
& >35 Tahun & 27 & 44 \\
& Total & 61 & 100 \\
& Tingkat Pendidikan: & & \\
SMA / SMK & 2 & 3 \\
D3 & 21 & 34 \\
S1 & 33 & 54
\end{tabular}




\begin{tabular}{llcc}
\multicolumn{1}{c}{ S2 } & 5 & 8 \\
S3 & - & - \\
Total & 61 & 100 \\
Pengalaman Kerja: & & \\
$1-2$ tahun & 4 & 6 \\
5 & $2-3$ tahun & 12 & 19 \\
& $>3$ tahun & 45 & 73 \\
Total & 61 & 100 \\
\hline
\end{tabular}

Sumber: Data diolah, 2018

Berdasarkan tabel di atas dapat dilihat nilai minimum untuk Transparency adalah 13 sedangkan nilai maksimumnya adalah 20. Mean untuk Transparency adalah17,66 dengan standar deviasinya 2,373. Hal ini berarti terjadi penyimpangan Transparency terhadap nilai rata-ratanya yaitu sebesar 2,373.

Tabel 3.

Hasil Statistik Deskriptif

\begin{tabular}{lccccc}
\hline & N & Minimum & Maximum & Mean & Std. Deviation \\
\hline Transparency & 61 & 13 & 20 & 17,66 & 2,373 \\
Budaya Organisasi & 61 & 11 & 20 & 17,18 & 2,579 \\
Kinerja & 61 & 13 & 20 & 17,41 & 2,171 \\
Valid N (listwise) & & & & & \\
& & & & &
\end{tabular}

Variabel budaya organisasi nilai minimumnya adalah 11 dan nilai maksimumnya adalah 20. Mean variabel budaya organisasi adalah 17,18 , hal ini berarti bahwa rata-rata nilai budaya organisasi sebesar 17,18. Standar deviasinya sebesar 2,579, hal ini berarti terjadi penyimpangan nilai budaya organisasi terhadap nilai rata-ratanya sebesar 2,579.

Variabel kinerja pegawai nilai minimumnya adalah 13 dan nilai maksimumnya adalah 20. Mean variabel kinerja individual adalah 17,41 , hal ini berarti rata-rata kinerja individual sebesar 17,41. Standar deviasinya sebesar 
2,171, hal ini berarti terjadi penyimpangan kinerja karyawan terhadap nilai rataratanya sebesar 2,171 .

Tabel 4.

Uji Kelayakan Model (Uji F)

\begin{tabular}{llrrrrr}
\hline Model & & Sum of Squares & df & Mean Square & F & Sig. \\
\hline 1 & Regression & 191,203 & 3 & 63,734 & 39,681 & $0.000^{\mathrm{a}}$ \\
& Residual & 91,551 & 57 & 1,606 & & \\
& Total & 282,754 & 60 & & & \\
\hline
\end{tabular}

Sumber: Data diolah, 2018

Berdasarkan Tabel diatas diperoleh nilai dari signifikansi 0,000 yang lebih kecil dari 0,05. Ini berarti bahwa ada pengaruh antara variabel Transparency, budaya organisasi dan interaksi variabel Transparency dengan budaya organisasi terhadap kinerja pegawai.

Tabel 5.

Nilai Koefisien Determinasi (Uji R $\mathbf{R}^{2}$ ) Model Summary

\begin{tabular}{lrrrr}
\hline & \multicolumn{2}{c}{ Model Summary } & \multicolumn{2}{c}{ Std. Error of the } \\
Model & $\mathrm{R}$ & R Square & Adjusted R Square & Estimate \\
\hline 1 & $.822^{\mathrm{a}}$ & .676 & .659 & 1.267
\end{tabular}

Sumber : Data diolah, 2018

Berdasarkan Tabel diatas nilai $\mathrm{R}^{2}$ sebesar 0,676 , ini berarti sebesar 67,6 persen (\%) variabel Transparency, budaya organisasi dan interaksi variabel Transparency dengan budaya organisasi berpengaruh terhadap kinerja pegawai, sedangkan sisanya sebesar 32,4 persen dipengaruhi oleh variabel lain yang tidak dimasukan dalam penelitian.

Analisis faktor adalah sebuah teknik yang digunakan untuk mencari faktor-faktor yang mampu menjelaskan hubungan atau korelasi antara berbagai indikator independen yang diobservasi. Analisis faktor merupakan perluasan dari analisis komponen utama. Digunakan juga untuk mengidentifikasi sejumlah faktor 
Anak Agung Ngurah Mahaputra Bismantara dan Made Gede Wirakusuma. Pengaruh ...

yang relatif kecil yang dapat digunakan untuk menjelaskan sejumlah besar variabel yang saling berhubungan.

Tabel 6.

Hasil Uji Analisis Faktor Variabel Transparency

\begin{tabular}{lllllll}
\hline Component & \multicolumn{3}{c}{ Initial Eigenvalues } & \multicolumn{3}{c}{ Extraction Sums of Squared Loadings } \\
& Total & \% of & Cumulative & Total & \% of & Cumulative \% \\
& & Variance & $\%$ & & Variance & \\
\hline 1 & 2.649 & 61.716 & 61.716 & 2.469 & 61.716 & 61.716 \\
2 & .704 & 17.596 & 79.312 & & & \\
3 & .537 & 13.421 & 92.733 & & & \\
4 & .291 & 7.267 & 100.00 & & & \\
\hline \multicolumn{5}{l}{ Sumber : Data diolah, 2018}
\end{tabular}

Berdasarkan hasil tersebut dapat dilihat bahwa nilai Extraction Sums of Squared Loadings pada Component tidak lebih dari 1 (satu) Component. Jadi, dapat disimpulkan bahwa variabel Transparency tidak terdapat multikolinearitas.

Tabel 7.

Hasil Uji Analisis Faktor Variabel Accountability

\begin{tabular}{|c|c|c|c|c|c|c|c|c|c|}
\hline \multirow[t]{2}{*}{$\begin{array}{l}\text { Compone } \\
\text { nt }\end{array}$} & \multicolumn{3}{|c|}{$\begin{array}{l}\text { Initial } \\
\text { Eigenvalues }\end{array}$} & \multicolumn{3}{|c|}{$\begin{array}{l}\text { Extraction Sums of } \\
\text { Squared Loadings }\end{array}$} & \multicolumn{3}{|c|}{$\begin{array}{l}\text { Rotation Sums of Squared } \\
\text { Loadings }\end{array}$} \\
\hline & $\begin{array}{l}\text { Tota } \\
1\end{array}$ & $\begin{array}{l}\% \text { of } \\
\text { Varian } \\
\text { ce }\end{array}$ & $\begin{array}{l}\text { Cumulat } \\
\text { ive } \%\end{array}$ & $\begin{array}{l}\text { Tota } \\
1\end{array}$ & $\begin{array}{l}\% \text { of } \\
\text { Varian } \\
\text { ce }\end{array}$ & $\begin{array}{l}\text { Cumulati } \\
\text { ve } \%\end{array}$ & $\begin{array}{l}\text { Tota } \\
1\end{array}$ & $\begin{array}{l}\% \text { of } \\
\text { Varian } \\
\text { ce }\end{array}$ & $\begin{array}{l}\text { Cumulati } \\
\text { ve } \%\end{array}$ \\
\hline 1 & $\begin{array}{l}1.54 \\
3\end{array}$ & 38.587 & 38.587 & $\begin{array}{l}1.54 \\
3\end{array}$ & 38.587 & 38.587 & $\begin{array}{l}1.49 \\
1\end{array}$ & 37.271 & 37.271 \\
\hline 2 & $\begin{array}{l}1.11 \\
2\end{array}$ & 27.790 & 66.376 & $\begin{array}{l}1.11 \\
2\end{array}$ & 27.790 & 66.376 & $\begin{array}{l}1.16 \\
4\end{array}$ & 29.105 & 66.376 \\
\hline 3 & .790 & 19.761 & 86.137 & & & & & & \\
\hline 4 & .555 & 13.863 & 100.000 & & & & & & \\
\hline
\end{tabular}

Sumber : Data diolah, 2018

Berdasarkan hasil tersebut dapat dilihat bahwa nilai Extraction Sums of Squared Loadings pada Component lebih dari 1 (satu) Component. Jadi, dapat disimpulkan bahwa terdapat multikolinearitas pada variabel Accountability. 
Tabel 8.

Hasil Uji Analisis Faktor Variabel Responsibility

\begin{tabular}{|c|c|c|c|c|c|c|c|c|c|}
\hline \multirow[t]{2}{*}{$\begin{array}{l}\text { Compone } \\
\text { nt }\end{array}$} & \multicolumn{3}{|c|}{$\begin{array}{l}\text { Initial } \\
\text { Eigenvalues }\end{array}$} & \multicolumn{3}{|c|}{$\begin{array}{l}\text { Extraction Sums of } \\
\text { Squared Loadings }\end{array}$} & \multicolumn{3}{|c|}{$\begin{array}{l}\text { Rotation Sums of } \\
\text { Squared Loadings }\end{array}$} \\
\hline & $\begin{array}{l}\text { Tot } \\
\text { al }\end{array}$ & $\begin{array}{l}\% \text { of } \\
\text { Varian } \\
\text { ce }\end{array}$ & $\begin{array}{l}\text { Cumula } \\
\text { tive } \%\end{array}$ & $\begin{array}{l}\text { Tot } \\
\text { al }\end{array}$ & $\begin{array}{l}\% \text { of } \\
\text { Varian } \\
\text { ce }\end{array}$ & $\begin{array}{l}\text { Cumulat } \\
\text { ive } \%\end{array}$ & $\begin{array}{l}\text { Tot } \\
\text { al }\end{array}$ & $\begin{array}{l}\% \text { of } \\
\text { Varian } \\
\text { ce }\end{array}$ & $\begin{array}{l}\text { Cumulat } \\
\text { ive } \%\end{array}$ \\
\hline 1 & $\begin{array}{l}1.35 \\
9\end{array}$ & 33.981 & 33.981 & $\begin{array}{l}1.35 \\
9\end{array}$ & 33.981 & 33.981 & $\begin{array}{l}1.35 \\
9\end{array}$ & 33.980 & 33.980 \\
\hline 2 & $\begin{array}{l}1.10 \\
1\end{array}$ & 27.535 & 61.516 & $\begin{array}{l}1.10 \\
1\end{array}$ & 27.535 & 61.516 & $\begin{array}{l}1.10 \\
1\end{array}$ & 27.536 & 61.516 \\
\hline 3 & .871 & 21.777 & 83.293 & & & & & & \\
\hline 4 & .668 & 16.707 & $\begin{array}{l}100.00 \\
0\end{array}$ & & & & & & \\
\hline
\end{tabular}

Berdasarkan hasil tersebut dapat dilihat bahwa nilai Extraction Sums of Squared Loadings pada Component lebih dari 1 (satu) Component. Jadi, dapat disimpulkan bahwa terdapat multikolinearitas pada variabel Responsibility.

Tabel 9.

Hasil Uji Analisis Faktor Variabel Independency

\begin{tabular}{|c|c|c|c|c|c|c|c|c|c|}
\hline \multirow[t]{2}{*}{$\begin{array}{l}\text { Compone } \\
\text { nt }\end{array}$} & \multicolumn{3}{|c|}{$\begin{array}{l}\text { Initial } \\
\text { Eigenvalues }\end{array}$} & \multicolumn{3}{|c|}{$\begin{array}{l}\text { Extraction Sums of } \\
\text { Squared Loadings }\end{array}$} & \multicolumn{3}{|c|}{$\begin{array}{l}\text { Rotation Sums of Squared } \\
\text { Loadings }\end{array}$} \\
\hline & $\begin{array}{l}\text { Tota } \\
1\end{array}$ & $\begin{array}{l}\% \text { of } \\
\text { Varian } \\
\text { ce }\end{array}$ & $\begin{array}{l}\text { Cumula } \\
\text { tive } \%\end{array}$ & $\begin{array}{l}\text { Tota } \\
1\end{array}$ & $\begin{array}{l}\% \text { of } \\
\text { Varian } \\
\text { ce }\end{array}$ & $\begin{array}{l}\text { Cumulat } \\
\text { ive } \%\end{array}$ & $\begin{array}{l}\text { Tota } \\
1\end{array}$ & $\begin{array}{l}\% \text { of } \\
\text { Varian } \\
\text { ce }\end{array}$ & $\begin{array}{l}\text { Cumulat } \\
\text { ive } \%\end{array}$ \\
\hline \multirow[t]{2}{*}{1} & 1.35 & 33.919 & 33.919 & 1.35 & 33.919 & 33.919 & 1.25 & 31.436 & 31.436 \\
\hline & 7 & & & 7 & & & 7 & & \\
\hline \multirow[t]{2}{*}{2} & 1.10 & 27.516 & 61.435 & 1.10 & 27.516 & 61.435 & 1.20 & 29.999 & 61.435 \\
\hline & 1 & & & 1 & & & 0 & & \\
\hline 3 & .844 & 21.108 & 82.543 & & & & & & \\
\hline 4 & .698 & 17.457 & 100.000 & & & & & & \\
\hline
\end{tabular}

Sumber : Data diolah, 2018

Berdasarkan hasil tersebut dapat dilihat bahwa nilai Extraction Sums of Squared Loadings pada Component lebih dari 1 (satu) Component. Jadi, dapat disimpulkan bahwa terdapat multikolinearitas pada variabel Independency. 
Tabel 10.

Uji Analisis Faktor Variabel Fairness

\begin{tabular}{|c|c|c|c|c|c|c|c|c|c|}
\hline \multirow[t]{2}{*}{$\begin{array}{l}\text { Compone } \\
\text { nt }\end{array}$} & \multicolumn{3}{|c|}{$\begin{array}{l}\text { Initial } \\
\text { Eigenvalues }\end{array}$} & \multicolumn{3}{|c|}{$\begin{array}{l}\text { Extraction Sums of Squared } \\
\text { Loadings }\end{array}$} & \multicolumn{3}{|c|}{$\begin{array}{l}\text { Rotation Sums of Squared } \\
\text { Loadings }\end{array}$} \\
\hline & $\begin{array}{l}\text { Tota } \\
1\end{array}$ & $\begin{array}{l}\% \text { of } \\
\text { Varian } \\
\text { ce }\end{array}$ & $\begin{array}{l}\text { Cumulat } \\
\text { ive } \%\end{array}$ & Total & $\begin{array}{l}\% \text { of } \\
\text { Varian } \\
\text { ce }\end{array}$ & $\begin{array}{l}\text { Cumulati } \\
\text { ve } \%\end{array}$ & $\begin{array}{l}\text { Tota } \\
1\end{array}$ & $\begin{array}{l}\% \text { of } \\
\text { Varian } \\
\text { ce }\end{array}$ & $\begin{array}{l}\text { Cumulati } \\
\text { ve } \%\end{array}$ \\
\hline \multirow[t]{2}{*}{1} & 1.37 & 34.425 & 34.425 & 1.35 & 34.425 & 34.425 & 1.22 & 30.598 & 30.598 \\
\hline & 7 & & & 7 & & & 4 & & \\
\hline \multirow[t]{2}{*}{2} & 1.05 & 26.360 & 60.785 & 1.05 & 26.360 & 60.785 & 1.20 & 30.187 & 60.785 \\
\hline & 4 & & & 4 & & & 7 & & \\
\hline 3 & .875 & 21.875 & 82.660 & & & & & & \\
\hline 4 & .694 & 17.340 & 100.000 & & & & & & \\
\hline
\end{tabular}

Sumber : Data diolah, 2018

Berdasarkan hasil tersebut dapat dilihat bahwa nilai Extraction Sums of Squared Loadings pada Component lebih dari 1 (satu) Component. Jadi, dapat disimpulkan bahwa terdapat multikolinearitas pada variabel Fairness.

Hasil Analisis Faktor pada 5 prinsip - prinsip Good Government Governance menunjukan bahwa prinsip Accountability, Responsibility, Independency, dan Fairness terdapat multikolinearitas sehingga tidak dapat digunakan sebagai variabel independen untuk dimoderasi oleh variabel Budaya Organisasi. Sedangkan prinsip Transparency adalah satu - satunya prinsip yang tidak menunjukan adanya multikolinearitas dalam analisis faktor tersebut. Hal ini membuat prinsip Transparency adalah prinsip terbaik berdasarkan analisis faktor untukdigunakan sebagai variabel independen yang dimoderasi oleh variabel Budaya Organisasi. 
Tabel 11.

Hasil Uji Hipotesis

\begin{tabular}{|c|c|c|c|c|c|}
\hline \multirow[b]{2}{*}{ Model } & \multicolumn{2}{|c|}{$\begin{array}{l}\text { Unstandardized } \\
\text { Coefficients }\end{array}$} & \multicolumn{3}{|c|}{$\begin{array}{l}\text { Standardized } \\
\text { Coefficients }\end{array}$} \\
\hline & $\mathrm{B}$ & Std. Error & Beta & $\mathrm{t}$ & Sig. \\
\hline (Constant) & .846 & .169 & & 5.012 & .000 . \\
\hline Transparency & -.050 & .126 & -.062 & -.399 & .691 \\
\hline Budaya Org & -.019 & .123 & -.024 & -.158 & .875 \\
\hline Interaksi & .099 & .173 & .080 & .570 & .571 \\
\hline \multicolumn{6}{|c|}{ a. Dependen Variable: absres } \\
\hline
\end{tabular}

Berdasarkan Tabel diatas dapat dibuat suatu model persamaan regresi yaitu sebagai berikut.

$$
Y=0,846-0,050 X_{1}-0,019 X_{2}+0,015 X_{1} X_{2}
$$

Pada Tabel 4.16, menunjukkan bahwa variabel $\mathrm{X}_{1}$ (Transparency) yang dimasukkan dalam regresi berpengaruh positif dan signifikan terhadap kinerja pegawai. Variabel $\mathrm{X}_{1}$ (Transparency) memberikan nilai parameter -0,050 dengan tingkat signifikasi 0,691 dan variabel budaya organisasi memberikan nilai koefisien parameter $-0,019$ dengan tingkat signifikasi 0,875 . Variabel moderat yang merupakan interaksi antara Transparancy dan budaya organisasi ternyata signifikan $(\operatorname{sig}=0,00)$ sehingga dapat disimpulkan bahwa variabel budaya organisasi merupakan variabel moderating.

\section{SIMPULAN}

Berdasarkan hasil analisis dan uraian pada bab-bab sebelumnya, maka dapat diperoleh simpulan adalah sebagai berikut:Penerapan Good Government Governance berpengaruh positif dan signifikan terhadap kinerja pegawai, sehingga hipotesis pertama dalam penelitian ini diterima.Budaya organisasi 
Anak Agung Ngurah Mahaputra Bismantara dan Made Gede Wirakusuma. Pengaruh ...

memoderasi pengaruh penerapan Good Government Governance terhadap kinerja pegawai, sehingga hipotesis kedua dalam penelitian ini diterima.

Penelitian yang dilakukan dapat memberikan kontribusi mengenai pengaruh penerapan Good Government Governance dan kinerja pegawai dengan budaya organisasi sebagai variabel pemoderasi. Berdasarkan hasil uji dalam penelitian ini dapat diketahui bahwa kinerja pegawai tidak hanya dipengaruhi secara parsial oleh penerapan Good Government Governancemelainkan adanya faktor kontijensi berupa variabel budaya organisasi yang mampu lebih meningkatkan kualitas pelayanan publik pada Dinas Penanaman Modal Kota Denpasar.Berdasarkan hasil penelitian maka perlu diperhatikan bahwa dalam meningkatkan kualitas pelayanan publik, manajemen instansi tidak hanya mempertimbangkan penerapan Good Government Governance melainkan juga harus memerhatikanbudaya organisasi di dalam kinerja pegawai pada Dinas Penanaman Modal Kota Denpasar.

Berdasarkan hasil penelitian dan simpulan yang diperoleh serta keterbatasan penelitian yang ada, maka dapat dikemukakan saran-saran sebagai berikut: Dinas Penanaman Modal Kota Denpasar diharapkan terus mengevaluasi kinerja pegawainya agar dapat memberikan pelayanan publik yang terbaik dan memuaskan masyarakat serta dapat meningkatkan kinerja instansi di Kota Denpasar. Dinas Penanaman Modal Kota Denpasar sebaiknya memerhatikan apakah budaya oganisasi sudah sesuai dengan tujuan instansi atau belum, karena budaya organisasi memengaruhi kinerja pegawai terutama pada prinsip Transparency dalam penerapan Good Government Governance. 


\section{REFERENSI}

Andani, V. A., \& Riduwan, A. (2015). Pengaruh Penerapan Prinsip-Prinsip Good Corporate Governance Pada Kinerja Pegawai. Jurnal Ilmu \& Riset Akuntansi.

Aprilia, R. (2016). Pengaruh Good Corporate Governance, Budaya Organisasi Dan Pengedalian Intern Terhadap Kinerja Organisasi Dengan Akuntabilitas Publiksebagai Variabel Intervening (Survey Terhadap Rumah Sakit di Kota Padang). JOM Fekon.

Buallay, A., Hamdan, A., \& Zureigat, Q. (2017). Corporate Governance and Firm Performance: Evidence from Saudi Arabia. Australasian Accounting, Business and Finance Journal. https://doi.org/10.14453/aabfj.v11i1.6

Buchloz, A. \&. (1978). A Reason for Differences on Corporate Social Reporting. Critical Perspectives on Accounting, 10, 521-547.

D., L., S., R., \& İ., T. (2007). Corporate Governance, Accounting Outcomes, and Organizational Performance. Accounting Review, 82(4), 963-1008.

Dwisastrawan, I. M., \& Suaryana, I. G. N. A. S. (2016). Pengaruh Langsung Dan Tidak Langsung Good Corporate Governance Terhadap Pengungkapan Tanggung Jawab Sosial Perusahaan. E-Jurnal Akuntansi Universitas Udayana, 14, 371-398.

Ekonomi, F., Akuntansi, M., Udayana, U., Ekonomi, F., Akuntansi, M., \& Udayana, U. (2015). Penerapan Good Governance Sebagai Variabel diakui secara nasional, juga memiliki lembaga sosial yang bersifat tradisional yang, 2, 311-325.

Ho, J. L. Y. (n.d.). Control Privatization, Changes in Incentives and Firm Performance : Evidence from China Control Privatization, Change in Incentives and Firm Performance : Evidence from China, 1-54.

Inastri, M. A. (2017). Pengaruh penerapan good corporate governance dan pengungkapan corporate soial responsibility pada nilai perusahaan. E-Jurnal Akuntansi Universitas Udayana, 21(2), 1400-1429.

Index, P., Loan, N. P., \& Analysis, P. (2016). Implementasi Good Corporate Governance Pada Kinerja, 16, 1461-1488.

Istighfarin, D., Gusti, N., \& Wirawati, P. (2005). Zartheit durch Reifung in der Linie: Persecuting Erzeugung von bakteriologisch sicheren 
Anak Agung Ngurah Mahaputra Bismantara dan Made Gede Wirakusuma. Pengaruh ...

Gefl??gelprodukten mit langer Haltbarkeit. Fleischwirtschaft, 85(2), 30-33.

Muliani, L. E., Yuniarta, G. A., \& Sinarwati, K. (2014). Pengaruh kinerja keuangan terhadap nilai perusahaan dengan pengungkapan corporate social responsibility dan good corporate governance sebagai variabel pemoderasi (studi kasus di bursa efek indonesia periode 2010-2012). E-Journal S1 Akuntansi Universitas Pendidikan Ganesha.

Puspitha, M. Y. (2016). Corporate Governance Pada Kinerja Perusahaan Fakultas Ekonomi dan Bisnis Universitas Udayana ( Unud ), Bali , Indonesia PENDAHULUAN Perbankan berkaitan erat dengan pembangunan ekonomi melalui jasa keuangan dalam hal menghimpun dan menyalurkan dana masyara, 3, 1978-2012.

Puspitha, M. Y., \& Sujana, I. K. (2016). Budaya Organisasi Pemoderasi Pengaruh Prinsip Good Corporate Governance Pada Kinerja Perusahaan Berbasis Balanced Scorecard. E-Jurnal Akuntansi Universitas Udayana. https://doi.org/ISSN: 2302-8559

Putri, I. A. D. (2012). Peranan Good Corporate Governance dan Budaya Terhadap Kinerja Organisasi. Jurnal Akuntansi \& Bisnis.

Putri, I. G. A. M. A. D. (2015). Sumber Daya Manusia, Good Corporate Governance, Dan Kinerja Perusahaan, XI(1), 29-34.

Putri, N. K. D. Y., \& Putra, I. M. P. D. (2017a). Pengaruh Prinsip-Prinsip Good Corporate Governance, Motivasi, dan Budaya Organisasi Terhadap Kinerja Karyawan. E-Jurnal Akuntansi Universitas Udayana.

Putri, N. K. D. Y., \& Putra, I. M. P. D. (2017b). Pengaruh Prinsip-Prinsip Good Corporate Governance, Motivasi, dan Budaya Organisasi Terhadap Kinerja Karyawan. E-Jurnal Akuntansi Universitas Udayana, 21, 1660-1688.

Ramdhaningsih, A., \& Utama, I. M. K. (2013). Pengaruh Indikator Good Corporate Governance Corporate Social Responsibility. E-Jurnal Akuntansi Universitas Udayana, 3(3), 65-82.

Sandraningsih, N. K. B., \& Putri, I. G. A. M. A. D. (2015). Pengaruh PrinsipPrinsip Good Corporate Governance Pada Kinerja Keuangan Lembaga Perkreditan Desa Kecamatan Abiansemal. E-Jurnal Akuntansi Universitas Udayana, 3(11), 878-893.

Sari, A. A. I. P., Putri, I. G. A. M. A. D., \& Ekonomi. (2014). Pengaruh Mekanisme Corporate Governance Pada Manajemen Laba Fakultas Ekonomi dan Bisnis Universitas Udayana Pendahuluan Seiring dengan laju perputaran waktu serta berkembangnya perekonomian di Indonesia maka semakin 
banyak kiat-kiat pintar yang dilakukan. Pengaruh Mekanisme Corporate Governance, 1, 94-104. https://doi.org/10.1097/00004647-200009000-00008

Sari, M. M. R. (2014). Persepsi Karyawan Atas Audit Manajemen Fakultas Ekonomi dan Bisnis Universitas Udayana ( Unud ), Bali , Indonesia, 3, 538553.

Shen, L., Farid, H., \& Mcpeek, M. A. (2008). Good Corporate Governance Memoderasi Pengaruh Financial Distress Terhadap Manajemen Laba. Evolution, 23, 1-14.

Soraya, B. E., \& Suardana, K. A. (2018). Budaya Organisasi Sebagai Pemoderasi Pengaruh Good Corporate Governance pada Kinerja Keuangan Bank Pembangunan Daerah Bali Fakultas Ekonomi dan Bisnis Universitas Udayana ( Unud ), Bali , Indonesia Fakultas Ekonomi dan Bisnis Universitas Udayana ( Unud ), 23(3), 2414-2443.

Surya Lestari, N. (2018). Pengaruh Ukuran Perusahaan dan Pengungkapan CSR Terhadap Nilai Perusahaan dengan GCG Sebagai Variabel Pemoderasi. EJournal Akuntansi Universitas Udayana, 23 (2), 1386-1414. Retrieved from https://ojs.unud.ac.id/index.php/Akuntansi/article/view/37565

Terhadap, G., \& Karyawan, K. (2013). Pengaruh Locus of Control Karyawan Dan Penerapan Prinsip-Prinsip Good Corporate.

Thasia, K., \& Devi, W. (2018). Pengaruh Prinsip-Prinsip Good Corporate Governance Pada Kualitas Informasi Keuangan Pdam Kabupaten Buleleng, $23,2311-2334$. 